\title{
Genetic Similarities among Wine Grape Cultivars Revealed by Restriction Fragment-length Polymorphism (RFLP) Analysis
}

\author{
John E. Bowers and Carole P. Meredith \\ Department of Viticulture and Enology, University of California, Davis, CA 95616
}

\begin{abstract}
Additional index words. Vitis vinifera, phenetic analysis, DNA polymorphism
Abstract. RFLP data were used to assess genetic similarity among 33 Vitis vinifera $L$. cultivars and one interspecific cultivar. A similarity matrix was constructed on the basis of the presence or absence of 49 bands generated by eight RFLP probes and cluster analysis was performed. The mean similarity index for all pairwise comparisons was 0.696 and ranged from 0.444 between 'St. Emilion' and the interspecific hybrid 'Salvador' to 0.952 between 'Chenin blanc' and 'Semillon'. Mean similarity among all $V$. vinifera cultivars was 0.705 . Several groupings of similar cultivars are consistent with historical reports and presumed geographic origins: 'Chardonnay' and 'Melon', 'Colombard' and 'Folle blanche', 'Gewürztraminer' and 'Trousseau', 'Cabernet franc' and 'Cabernet Sauvignon', 'Mission' and 'Palomino'. The similarity between 'Mission' and 'Palomino' is the first genetic evidence to support the putative Spanish origin of 'Mission'. Some groupings are unexpected ('Sauvignon blanc' and 'Gewürztraminer', 'Chenin blanc' and 'Semillon') because the cultivars are not thought to have originated in the same regions. While some relationships suggested by this study may be artifacts of RFLP analysis or of the statistical method, they raise questions for further genetic inquiry into the origins of grape cultivars.
\end{abstract}

Grape is not only one of the oldest crops but also one of the most widely distributed, grown in all temperate regions of the world as well as some tropical locations. The number of cultivars is estimated at about 5000 (Alleweldt, 1988). While the earliest cultivation may have occurred in the region between the Black and Caspian Seas, there is ample archeological evidence for early Bronze Age cultivation in other locations around the Mediterranean Sea (Zohary and Hopf, 1993). It is thus likely that early cultivars arose from independent in situ domestication of wild vines in many locations. Additional cultivars no doubt arose as chance seedlings or as sports of existing cultivars and some are the result of deliberate crosses made since the late 19th century.

Grapes and wine were, and still are, dietary staples in Mediterranean cultures, and wine and raisins were important items in early Mediterranean trade. As successive dominant cultures expanded and colonized new areas, autochthonous cultivars were carried along and established in new areas. The modern distribution of grape cultivars thus reflects not only the processes of domestication, mutation and hybridization, but also extensive migration. Consequently, the geographic origin of a cultivar may be far from the region with which it is most strongly identified today.

The origins of and relationships between some grape cultivars have been inferred from historical documents and morphological features (e.g., Dion, 1959). But historical descriptions of grapevines were minimal and the ancient cultivar names were rarely the same as those used today, so conclusions drawn from these sources are tenuous. The morphological characteristics of grape cultivars, particularly leaf morphology, have been studied in great detail and are the basis for cultivar identification today (ampelography). However, a single mutation can cause a significant morphological difference that might obscure an otherwise close relationship

Received for publication 20 Nov. 1995. Accepted for publication 26 Mar. 1996. This research was supported by funds from the Winegrape Inspection Program and the Fruit Tree, Nut Tree and Grapevine Improvement Advisory Board, both of the California Dept. of Food and Agriculture. The cost of publishing this paper was defrayed in part by the payment of page charges. Under postal regulations, this paper therefore must be hereby marked advertisement solely to indicate this fact. between two cultivars. DNA marker data offer an alternative approach by which to explore the relationships among grape cultivars. Genetic distance measures obtained from DNA marker data have been shown to accurately reflect known genetic relationships in previous studies in other plant species (reviewed in Dudley, 1994).

We present here a phenetic analysis of RFLP data obtained from 33 Vitis vinifera cultivars and one interspecific hybrid cultivar. This group includes most of the wine cultivars of current economic importance in California and encompasses material presumed to have originated in diverse regions of Europe and western Asia. It must be emphasized that the relationships that are revealed in this study are phenetic, not phylogenetic, since the taxa being analyzed are not naturally evolved but are the product of human selection acting upon genetic variability generated by natural and artificial means. For this reason, the method chosen for this study was cluster analysis, by which the cultivars were grouped hierarchically according to shared characters, rather than by several other statistical methods for inferring evolutionary relationships that require certain assumptions regarding mutation rates and parsimony. The limitations of restriction fragment data for phylogenetic analysis are well known (Swofford and Olsen, 1990). Nevertheless this type of information is as valuable for phenetic analysis as is any binary character state and has the additional advantage of directly reflecting the genotype since it is unaffected by environment or developmental stage.

\section{Materials and Methods}

All plant material was obtained from the vineyards of the Univ. of California, Davis. The cultivar names used here are those in general use in California. Although some of these names are thought to be synonymous with prime names used in Europe (e.g., 'Napa Gamay' and 'Valdiguié'), we consider it premature to substitute the prime names until the synonymy is confirmed by genetic analysis.

DNA extraction and Southern analysis were as described in Bowers et al. (1993). Briefly, DNA was extracted by a modified 
CTAB procedure, digested with either HinDIII or EcoRI, and probed with eight random genomic probes isolated from 'Thompson Seedless' V. vinifera. Each cultivar was scored for the presence or absence of 49 bands chosen on the basis of their reproducibility and clarity.

A similarity matrix was constructed with the Dice similarity coefficient (Dice, 1945), which represents the proportion of shared bands and is identical to the similarity coefficient of $\mathrm{Nei}$ and $\mathrm{Li}$ (1979). Dissimilarity was calculated as 1 minus similarity. Cluster analysis was performed with NTSYS-pc version 1.80, a numerical taxonomy and multivariate analysis software package (Rohlf, 1993). Comparisons to the results of Bourquin et al. (1993) were made by calculating Dice similarity coefficients from the raw RFLP data illustrated in their paper.

\section{Results and Discussion}

The mean similarity index for all pairwise comparisons was 0.696 and ranged from a low of 0.444 between 'St. Emilion' and 'Salvador' to a high of 0.952 between 'Chenin blanc' and 'Semillon' (Table 1). The low similarity between 'Salvador' and the other cultivars (mean similarity index $=0.552$ ) was expected since, unlike the others, 'Salvador' is not a pure vinifera cultivar, but is a complex interspecific hybrid of vinifera, rupestris, and lincecumii (Galet, 1988). Mean similarity among all $V$. vinifera cultivars was 0.705 .

Similar results were obtained with unweighted pair-group method, arithmetic average (UPGMA), weighted pair-group method, arithmetic average (WPGMA) and neighbor joining, although the cophenetic correlation with the original data was highest with UPGMA $(r=0.75)$. The clusters produced by UPGMA are illustrated as a dendrogram in Fig. 1. The branch point at which any two cultivars diverge indicates their degree of similarity.

It must be emphasized that the dendrogram illustrates the relative similarity within and between clusters of cultivars, but does not imply an evolutionary path by which the cultivars might have originated. The object of this study was to examine the extent to which cultivars share genetic characters, in this case restriction fragments. It is reasonable to infer a common origin for two cultivar with a very high proportion of shared characters. However, lesser degrees of fragment sharing may not be biologically meaningful, given the limitations inherent in both restriction fragment data and cluster analysis. It would be incorrect to draw conclusions from the larger clusters on the basis of the limited data analyzed in this study.

Several very close relationships are evident in Fig. 1, all of which were consistently revealed by all the clustering methods used. Some of these relationships confirm previously known or suspected connections, but others were not anticipated.

Table 1. Similarity matrix for 33 Vitis vinifera cultivars and 1 interspecific hybrid cultivar. Similarities were calculated as described in the text.

\begin{tabular}{|c|c|c|c|c|c|c|c|c|c|}
\hline & Chardonnay & Melon & Colombard & Burger & $\begin{array}{c}\text { Folle } \\
\text { blanche }\end{array}$ & Durif & Gewürztraminer & $\begin{array}{c}\text { Sauvignon } \\
\text { blanc }\end{array}$ & Trousseau \\
\hline Chardonnay & 1.00 & & & & & & & & \\
\hline Melon & 0.91 & 1.00 & & & & & & & \\
\hline Colombard & 0.86 & 0.81 & 1.00 & & & & & & \\
\hline Burger & 0.79 & 0.83 & 0.83 & 1.00 & & & & & \\
\hline Folle blanche & 0.84 & 0.88 & 0.83 & 0.90 & 1.00 & & & & \\
\hline Durif & 0.81 & 0.76 & 0.80 & 0.86 & 0.82 & 1.00 & & & \\
\hline Gewürztraminer & 0.83 & 0.86 & 0.82 & 0.88 & 0.79 & 0.81 & 1.00 & & \\
\hline Sauvignon blanc & 0.76 & 0.84 & 0.79 & 0.86 & 0.76 & 0.78 & 0.93 & 1.00 & \\
\hline Trousseau & 0.77 & 0.81 & 0.81 & 0.83 & 0.73 & 0.80 & 0.91 & 0.88 & 1.00 \\
\hline Plavac & 0.76 & 0.74 & 0.74 & 0.86 & 0.76 & 0.83 & 0.80 & 0.77 & 0.84 \\
\hline Zinfandel & 0.76 & 0.70 & 0.80 & 0.82 & 0.77 & 0.74 & 0.81 & 0.73 & 0.80 \\
\hline Riesling & 0.80 & 0.74 & 0.79 & 0.81 & 0.81 & 0.83 & 0.76 & 0.77 & 0.79 \\
\hline Chenin blanc & 0.80 & 0.79 & 0.84 & 0.86 & 0.76 & 0.78 & 0.89 & 0.82 & 0.84 \\
\hline Semillon & 0.79 & 0.73 & 0.83 & 0.80 & 0.70 & 0.77 & 0.84 & 0.76 & 0.83 \\
\hline Pinot noir & 0.84 & 0.88 & 0.78 & 0.80 & 0.80 & 0.73 & 0.88 & 0.81 & 0.78 \\
\hline Napa Gamay & 0.77 & 0.71 & 0.81 & 0.73 & 0.73 & 0.71 & 0.73 & 0.65 & 0.71 \\
\hline Petite Sirah & 0.73 & 0.62 & 0.77 & 0.68 & 0.63 & 0.76 & 0.68 & 0.60 & 0.67 \\
\hline Nebbiolo & 0.71 & 0.60 & 0.70 & 0.67 & 0.57 & 0.70 & 0.76 & 0.73 & 0.79 \\
\hline Cabernet franc & 0.71 & 0.70 & 0.65 & 0.67 & 0.62 & 0.65 & 0.71 & 0.73 & 0.74 \\
\hline Cabernet Sauvignon & 0.76 & 0.74 & 0.79 & 0.81 & 0.76 & 0.78 & 0.80 & 0.82 & 0.79 \\
\hline Merlot & 0.68 & 0.67 & 0.71 & 0.73 & 0.68 & 0.67 & 0.73 & 0.74 & 0.76 \\
\hline Ruby Cabernet & 0.73 & 0.71 & 0.71 & 0.68 & 0.68 & 0.67 & 0.73 & 0.79 & 0.71 \\
\hline Carignane & 0.65 & 0.60 & 0.68 & 0.65 & 0.57 & 0.72 & 0.69 & 0.71 & 0.77 \\
\hline St Emilion & 0.65 & 0.68 & 0.73 & 0.84 & 0.74 & 0.72 & 0.78 & 0.76 & 0.82 \\
\hline Mission & 0.77 & 0.76 & 0.71 & 0.73 & 0.73 & 0.63 & 0.72 & 0.74 & 0.62 \\
\hline Palomino & 0.73 & 0.72 & 0.68 & 0.74 & 0.74 & 0.64 & 0.73 & 0.71 & 0.64 \\
\hline Barbera & 0.80 & 0.74 & 0.74 & 0.76 & 0.76 & 0.74 & 0.76 & 0.68 & 0.70 \\
\hline Viognier & 0.77 & 0.71 & 0.76 & 0.73 & 0.78 & 0.76 & 0.73 & 0.70 & 0.67 \\
\hline Malvasia & 0.68 & 0.71 & 0.67 & 0.73 & 0.73 & 0.62 & 0.68 & 0.65 & 0.67 \\
\hline Muscat blanc & 0.72 & 0.71 & 0.67 & 0.59 & 0.64 & 0.58 & 0.72 & 0.74 & 0.62 \\
\hline Alicante Bouschet & 0.65 & 0.63 & 0.63 & 0.70 & 0.70 & 0.68 & 0.65 & 0.62 & 0.63 \\
\hline Grenache & 0.60 & 0.59 & 0.59 & 0.70 & 0.65 & 0.68 & 0.65 & 0.67 & 0.68 \\
\hline Thompson Seedless & 0.60 & 0.63 & 0.59 & 0.70 & 0.65 & 0.68 & 0.70 & 0.71 & 0.68 \\
\hline Salvador & 0.58 & 0.51 & 0.65 & 0.52 & 0.57 & 0.61 & 0.53 & 0.55 & 0.51 \\
\hline
\end{tabular}


'Chardonnay' and 'Melon'. 'Chardonnay' is well-known as the preeminent white wine grape in the Burgundy and Champagne regions of France and has been grown in Burgundy at least since the 14th century and possibly since Roman times (Viala and
Vermorel, 1903). 'Melon', on the other hand, is found primarily in the western part of the Loire Valley. However, 'Melon' was once also widely grown in Burgundy (Galet, 1990), perhaps as long ago as the 13th century (Viala and Vermorel, 1901) and thus its strong

Table 1. Continued.

\begin{tabular}{|c|c|c|c|c|c|c|c|c|c|}
\hline & Plavac & Zinfandel & Riesling & $\begin{array}{l}\text { Chenin } \\
\text { blanc }\end{array}$ & Semillon & $\begin{array}{l}\text { Pinot } \\
\text { noir }\end{array}$ & $\begin{array}{c}\text { Napa } \\
\text { Gamay }\end{array}$ & $\begin{array}{l}\text { Petite } \\
\text { Sirah }\end{array}$ & Nebbiolc \\
\hline$\overline{\text { Plavac }}$ & 1.00 & & & & & & & & \\
\hline Zinfandel & 0.83 & 1.00 & & & & & & & \\
\hline Riesling & 0.77 & 0.83 & 1.00 & & & & & & \\
\hline Chenin blanc & 0.77 & 0.73 & 0.68 & 1.00 & & & & & \\
\hline Semillon & 0.76 & 0.72 & 0.67 & 0.95 & 1.00 & & & & \\
\hline Pinot noir & 0.71 & 0.72 & 0.67 & 0.90 & 0.85 & 1.00 & & & \\
\hline Napa Gamay & 0.65 & 0.70 & 0.65 & 0.84 & 0.83 & 0.83 & 1.00 & & \\
\hline Petite Sirah & 0.65 & 0.70 & 0.65 & 0.80 & 0.79 & 0.74 & 0.82 & 1.00 & \\
\hline Nebbiolo & 0.73 & 0.68 & 0.68 & 0.82 & 0.81 & 0.71 & 0.74 & 0.75 & 1.00 \\
\hline Cabernet franc & 0.73 & 0.63 & 0.68 & 0.64 & 0.67 & 0.57 & 0.51 & 0.45 & 0.68 \\
\hline Cabernet Sauvignon & 0.77 & 0.73 & 0.73 & 0.73 & 0.71 & 0.67 & 0.65 & 0.60 & 0.73 \\
\hline Merlot & 0.74 & 0.65 & 0.65 & 0.74 & 0.78 & 0.63 & 0.67 & 0.56 & 0.79 \\
\hline Ruby Cabernet & 0.65 & 0.65 & 0.74 & 0.60 & 0.59 & 0.63 & 0.52 & 0.51 & 0.60 \\
\hline Carignane & 0.71 & 0.62 & 0.71 & 0.75 & 0.74 & 0.65 & 0.64 & 0.68 & 0.75 \\
\hline St. Emilion & 0.76 & 0.76 & 0.76 & 0.76 & 0.74 & 0.65 & 0.64 & 0.59 & 0.67 \\
\hline Mission & 0.65 & 0.65 & 0.65 & 0.70 & 0.64 & 0.68 & 0.58 & 0.52 & 0.57 \\
\hline Palomino & 0.67 & 0.62 & 0.58 & 0.71 & 0.65 & 0.70 & 0.60 & 0.50 & 0.58 \\
\hline Barbera & 0.73 & 0.73 & 0.68 & 0.73 & 0.71 & 0.71 & 0.65 & 0.65 & 0.68 \\
\hline Viognier & 0.70 & 0.65 & 0.65 & 0.70 & 0.73 & 0.68 & 0.67 & 0.56 & 0.65 \\
\hline Malvasia & 0.79 & 0.70 & 0.65 & 0.74 & 0.68 & 0.73 & 0.62 & 0.56 & 0.65 \\
\hline Muscat blanc & 0.57 & 0.60 & 0.61 & 0.70 & 0.64 & 0.77 & 0.62 & 0.57 & 0.65 \\
\hline Alicante Bouschet & 0.67 & 0.62 & 0.67 & 0.71 & 0.75 & 0.70 & 0.68 & 0.58 & 0.62 \\
\hline Grenache & 0.71 & 0.62 & 0.67 & 0.67 & 0.70 & 0.60 & 0.59 & 0.47 & 0.67 \\
\hline Thompson Seedless & 0.67 & 0.56 & 0.71 & 0.67 & 0.65 & 0.65 & 0.49 & 0.53 & 0.62 \\
\hline \multirow[t]{2}{*}{ Salvador } & 0.55 & 0.54 & 0.59 & 0.55 & 0.52 & 0.52 & 0.56 & 0.55 & 0.50 \\
\hline & $\begin{array}{c}\text { Cabernet } \\
\text { franc }\end{array}$ & $\begin{array}{c}\text { Cabernet } \\
\text { Sauvignon }\end{array}$ & Merlot & $\begin{array}{c}\text { Ruby } \\
\text { Cabernet }\end{array}$ & Carignane & St. Emilion & Mission & Palomino & Barbera \\
\hline Cabernet franc & 1.00 & & & & & & & & \\
\hline Cabernet Sauvignon & 0.86 & 1.00 & & & & & & & \\
\hline Merlot & 0.79 & 0.84 & 1.00 & & & & & & \\
\hline Ruby Cabernet & 0.74 & 0.74 & 0.71 & 1.00 & & & & & \\
\hline Carignane & 0.71 & 0.67 & 0.68 & 0.77 & 1.00 & & & & \\
\hline St. Emilion & 0.71 & 0.71 & 0.73 & 0.68 & 0.78 & 1.00 & & & \\
\hline Mission & 0.70 & 0.70 & 0.67 & 0.71 & 0.60 & 0.60 & 1.00 & & \\
\hline Palomino & 0.71 & 0.71 & 0.68 & 0.72 & 0.62 & 0.65 & 0.88 & 1.00 & \\
\hline Barbera & 0.68 & 0.73 & 0.65 & 0.56 & 0.58 & 0.71 & 0.70 & 0.71 & 1.00 \\
\hline Viognier & 0.74 & 0.79 & 0.71 & 0.62 & 0.55 & 0.64 & 0.76 & 0.77 & 0.79 \\
\hline Malvasia & 0.65 & 0.65 & 0.67 & 0.62 & 0.64 & 0.68 & 0.62 & 0.68 & 0.65 \\
\hline Muscat blanc & 0.57 & 0.61 & 0.58 & 0.71 & 0.64 & 0.51 & 0.71 & 0.72 & 0.61 \\
\hline Alicante Bouschet & 0.62 & 0.57 & 0.68 & 0.63 & 0.65 & 0.65 & 0.55 & 0.65 & 0.52 \\
\hline Grenache & 0.67 & 0.62 & 0.73 & 0.63 & 0.65 & 0.70 & 0.59 & 0.65 & 0.57 \\
\hline Thompson Seedless & 0.62 & 0.57 & 0.63 & 0.68 & 0.70 & 0.65 & 0.64 & 0.61 & 0.62 \\
\hline \multirow[t]{2}{*}{ Salvador } & 0.55 & 0.59 & 0.47 & 0.56 & 0.58 & 0.44 & 0.61 & 0.67 & 0.55 \\
\hline & Viognier & Malvasia & $\begin{array}{c}\text { Muscat } \\
\text { blanc }\end{array}$ & $\begin{array}{l}\text { Alicante } \\
\text { Bouschet }\end{array}$ & Grenache & $\begin{array}{c}\text { Thompson } \\
\text { Seedless }\end{array}$ & Salvador & & \\
\hline Viognier & 1.00 & & & & & & & & \\
\hline Malvasia & 0.62 & 1.00 & & & & & & & \\
\hline Muscat blanc & 0.67 & 0.71 & 1.00 & & & & & & \\
\hline Alicante Bouschet & 0.63 & 0.68 & 0.59 & 1.00 & & & & & \\
\hline Grenache & 0.68 & 0.59 & 0.55 & 0.85 & 1.00 & & & & \\
\hline Thompson Seedless & 0.59 & 0.59 & 0.59 & 0.70 & 0.75 & 1.00 & & & \\
\hline Salvador & 0.65 & 0.51 & 0.61 & 0.52 & 0.52 & 0.48 & 1.00 & & \\
\hline
\end{tabular}




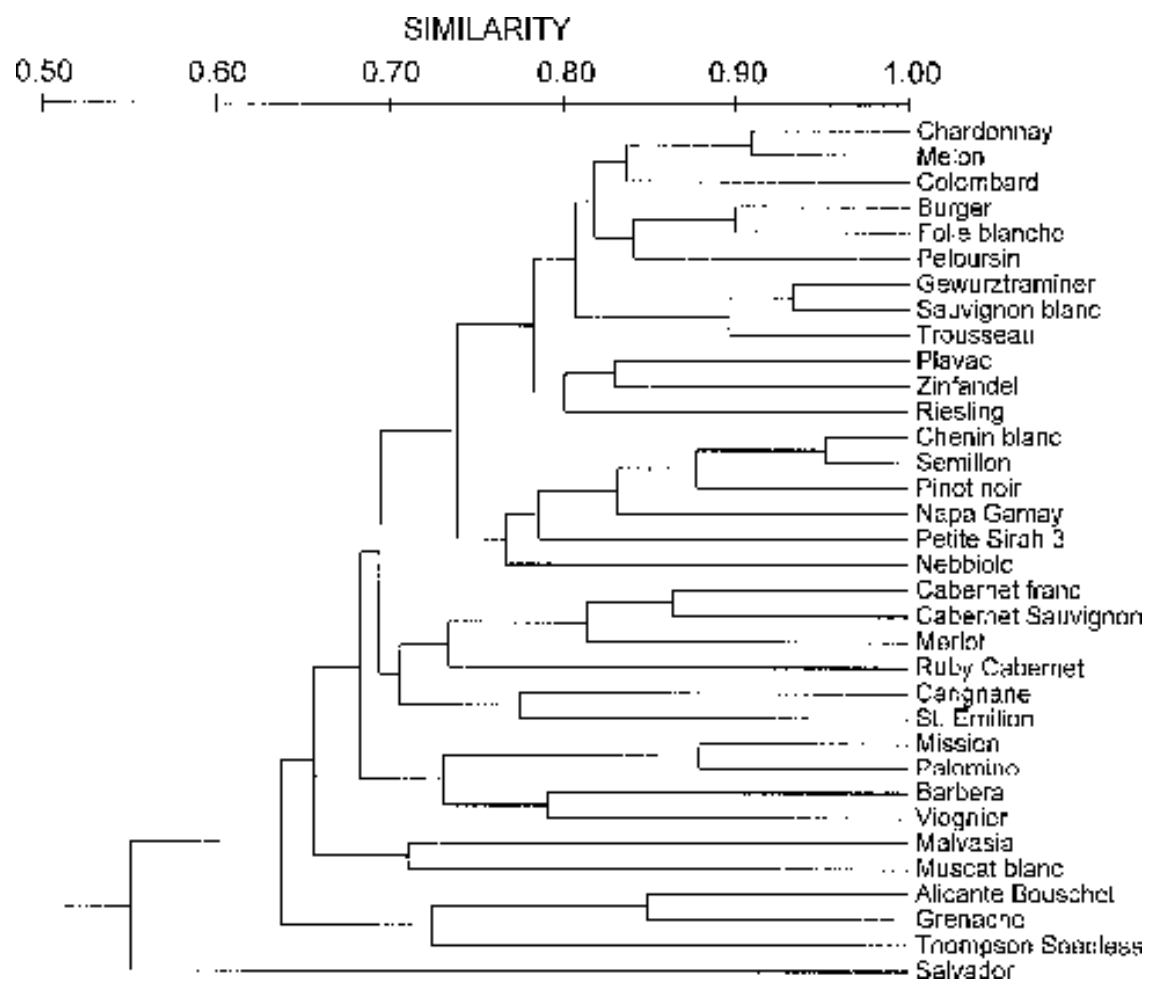

The only historical evidence that links 'Sauvignon' to 'Gewürztraminer' and 'Trousseau' is a mention of 'Sauvignon blanc' being grown in Alsace in 1789 (Viala and Vermorel, 1901). Bourquin et al. (1993) did not find such a strong similarity between 'Sauvignon' and 'Gewürztraminer' (only 75\% shared bands), although they did find a fairly high similarity between 'Gewürztraminer' and 'Trousseau' $(82 \%)$.

The 'Sauvignon blanc' grown in California is morphologically and enologically true to type and so it is not likely that the vine we analyzed was incorrectly identified. The high proportion of shared bands observed in this study may be simply a chance occurrence, reflecting sampling error due to the limited amount of the genome represented by the 49 RFLP bands examined here. The genetic relationship between 'Sauvignon' and 'Gewürztraminer' is being further investigated at microsatellite loci (Bowers and Meredith, unpublished results).

'Chenin blanc' and 'Semillon'. Of the 35 cultivars examined in this study, these two were the most similar, with $95 \%$ shared fragments. Bourquin et al. (1993) also found

Fig. 1. Dendrogram illustrating UPGMA cluster analysis of 34 grape cultivars. The branch point at which two cultivars diverge indicates the degree of similarity. Certain cultivars are considered to have the following European synonyms: 'Burger' ('Monbadon'), 'Zinfandel' ('Primitivo'), 'Napa Gamay' ('Valdiguié'), 'Petite Sirah 3' ('Durif'), 'Thompson Seedless' ('Sultanina'), 'Salvador' ('Siebel 128').

similarity (91\% shared fragments) to 'Chardonnay' may reflect a common origin, especially considering the morphological resemblance between these two cultivars. Bourquin et al. (1993) also found a high similarity between these two cultivars (84\% shared fragments).

'Burger' and 'Folle blanche'. 'Burger' is thought to be a synonym for 'Monbadon', an undistinguished French cultivar once associated primarily with the Charente region of southwestern France and now found in only a few locations in France. 'Folle blanche', now in decline, was once widely used for brandy and wine in Charente and other parts of southwestern France. Thus, the similarity $(90 \%)$ between these two cultivars is accompanied by a common geographic thread, although they are not morphologically similar.

'Gewürztraminer', 'Sauvignon blanc', and 'Trousseau'. The similarity between 'Gewürztraminer' and 'Trousseau' (91\%) is not surprising since they are somewhat similar morphologically and both are strongly associated with the northeastern parts of France. 'Gewürztraminer' is associated with the Alsace region, where it has been known since the 16th century and 'Trousseau' has been grown for centuries in the adjacent Jura region (Viala and Vermorel, 1901).

The association of 'Sauvignon blanc' with these two varieties (similarity indices of $93 \%$ and $88 \%$ with 'Gewürztraminer' and 'Trousseau', respectively) is unexpected, however. 'Sauvignon blanc' is widely grown in France, but is most strongly associated not with the northeastern French regions of Alsace and Jura but with the Bordeaux region in the southwest, where it has been grown at least since the 18th century (Viala and Vermorel, 1901).
'Semillon' to the most similar to 'Chenin blanc' in their study (85\% shared fragments). 'Chenin blanc' has been grown in the Loire Valley of France for more than 1000 years and is thought to have originated as a white fruited sport of a wild vine in this region (Viala and Vermorel, 1901). Today, its cultivation is still concentrated in the Loire Valley (Galet, 1990). 'Semillon', on the other hand, is thought to have originated some distance away to the south in Bordeaux, where its cultivation has been documented for at least 200 years (Viala and Vermorel, 1901). Despite their apparent geographic distance, the strong genetic similarity suggests a possible historical connection between these two cultivars that warrants further investigation.

'Cabernet franc', 'Cabernet Sauvignon', and 'Merlot'. The clustering of these three cultivars is consistent with both their morphological resemblance and their long geographic association with the Bordeaux region of France as far back as the early 17th century (Viala and Vermorel, 1901, 1905). 'Cabernet franc' and 'Cabernet Sauvignon' are the most similar $(86 \%$ shared fragments), with each being slightly less similar to 'Merlot' (79\% and $84 \%$, respectively.) Bourquin et al. (1993) detected a comparable degree of similarity among these three cultivars $(80 \%$ for ' $C a b e r n e t$ franc' and 'Cabernet Sauvignon', $82 \%$ for 'Cabernet franc' and 'Merlot', 84\% for 'Cabernet Sauvignon' and 'Merlot').

'Ruby Cabernet'. The clustering of this cultivar with the above group is expected, since 'Ruby Cabernet' is the result of a cross between 'Cabernet Sauvignon' and 'Carignane' (Olmo, 1948). The similarity between 'Ruby Cabernet' and its parents was almost identical (74\% for 'Cabernet Sauvignon', 76\% for 'Carignane') and the closer grouping with 'Cabernet Sauvignon' is evidently an artifact of the clustering process.

'Mission' and 'Palomino'. 'Mission' was brought to what is now California from Mexico in the 18th century by Catholic missionaries. It is presumed to be of Spanish origin, although no specific Spanish variety has been identified. The observation that 'Mission' is more similar (88\%) to the classic Spanish grape 'Palomino' than to any other cultivar in this group is the first 
genetic evidence for a Spanish origin for 'Mission'.

'Malvasia' and 'Muscat blanc'. The grouping of these two cultivars is intriguing, because both have long been grown throughout the Mediterranean region and both are thought to be ancient cultivars of Middle Eastern origin. A common origin is also suggested by the intensely aromatic flavor of both cultivars. The actual similarity value ( $71 \%$ ) is too low, however, to bring strong support to the notion.

'Grenache' and 'Alicante Bouschet'. 'Grenache' is one of the parents of 'Alicante Bouschet' (Galet, 1990), so the similarity between these two cultivars $(85 \%)$ is not unexpected. (The other parent, 'Petit Bouschet', was not analyzed.)

While a very high proportion of shared fragments, such as were found between 'Chenin blanc' and 'Semillon' or 'Chardonnay' and 'Melon', is strongly suggestive of a common origin, great caution must be exercised in interpreting these results because they are based on a small sample of the genome. Nevertheless, some of the very close relationships noted above are intriguing and invite further investigation.

Many of today's major grape cultivars are documented in historical writings. Some are presumed to have originated in antiquity and to have migrated with successive Mediterranean cultures, while others are thought to have more recent origins in their areas of current cultivation. Analysis of cultivar relationships at the DNA level may provide the first objective and convincing evidence with which to elucidate the history of this venerable and well-traveled crop.

\section{Literature Cited}

Alleweldt, G. 1988. The genetic resources of Vitis. Genetic and geographic origin of grape cultivars, their prime names and synonyms. 2nd ed. Federal Research Center for Grape Breeding, Geilweilerhof, Germany.
Bourquin, J.-C., A. Sonko, L. Otten, and B. Walter. 1993. Restriction fragment length polymorphism and molecular taxonomy in Vitis vinifera L. Theor. Appl. Genet. 87:431-438.

Bowers, J.E., E.B. Bandman, and C.P. Meredith. 1993. DNA fingerprint characterization of some wine grape cultivars. Amer. J. Enol. Viticult. 44:266-274.

Dice, L.R. 1945. Measures of the amount of ecologic association between species. Ecology 26:297-302.

Dion, R. 1959. Histoire de la vigne et du vin en France. Flammarion, France.

Dudley, J.W. 1994. Comparison of genetic distance estimators using molecular data. Proc. Symp. Analysis of Molecular Marker Data. Amer. Soc. Hort. Sci., Alex., Va. p. 3-7.

Galet, P. 1988. Cépages et Vignobles de France. Tome I. Les Vignes Américaines. 2nd ed. Imprimerie Charles Dehan, Montpellier, France.

Galet, P. 1990. Cépages et Vignobles de France. Tome II. L'Ampélographie Française. 2nd ed. Imprimerie Charles Dehan, Montpellier, France.

Nei, M. and W.-H. Li. 1979. Mathematical model for studying genetic variation in terms of restriction endonucleases. Proc. Natl. Acad. Sci. USA 76:5269-5273.

Olmo, H. P. 1948. 'Ruby Cabernet' and 'Emerald Riesling': Two new table-wine grape varieties. Univ. Calif. Agr. Expt. Sta. Bul. 704.

Rohlf, F. J. 1993. NTSYS-pc. Numerical taxonomy and multivariate analysis system. Version 1.80. Exeter Software, Setauket, New York.

Swofford, D.L. and G.J. Olsen. 1990. Phylogeny reconstruction, p. 411501. In: D.M. Hillis and C. Moritz (eds.). Molecular systematics. Sinauer Associates, Sunderland, Mass.

Viala, P. and V. Vermorel. 1901. Ampelographie, Tome II. Masson et Cie, Paris.

Viala, P. and V. Vermorel. 1903. Ampelographie, Tome IV. Masson et Cie, Paris.

Viala, P. and V. Vermorel. 1905. Ampelographie, Tome VI. Masson et Cie, Paris.

Zohary, D. and M. Hopf. 1993. Domestication of plants in the Old World: The origin and spread of cultivated plants in West Asia, Europe, and the Nile Valley. 2nd ed. Oxford Univ. Press, New York. 